\title{
Geneza „dwóch Testamentów” Pisma Świętego
}

W naszym dzisiejszym języku religijnym i teologicznym przychodzi nam bardzo łatwo posługiwać się tak nam bliskimi, niemal naturalnymi określeniami, jak „Stary” i „Nowy Testament”. Jest to coś tak oczywistego, że na ogół nie zastanawiamy się nad tym, jaka jest geneza tych określeń i jakie jest ich właściwe znaczenie, a tym samym także nad tym, jakie przesłanie teologiczne jest $w$ nich zawarte i jaka towarzyszy im nośność eklezjalna. W tym miejscu zamierzamy zatem pokazać, w jaki sposób doszło do utrwalenia się tych określeń w pierwotnym języku chrześcijańskim oraz przynajmniej ogólnie wskazać, jakie w tym utrwaleniu byłoby zawarte przesłanie teologiczno-eklezjalne, na które także dzisiaj należałoby zwrócić uwagę.

W czasach św. Ireneusza, ok. 180 roku cztery Ewangelie i listy św. Pawła stanowiły już podstawę literacką chrześcijańskiej części Pism (Scripturae) $)^{2}$, wyraźnie wpisując się w życie wspólnoty kościelnej jako nieodłączny punkt odniesienia określający jej tożsamość i jej przesłanie w relacji do Boga i do świata, ale także w świadomość ówczesnego społeczeństwa, które zdawało sobie sprawę z pojawienia się nowego typu pism, które w znacznej mierze dotyczyły właśnie spraw obyczajowych, a zatem także społecznych. Ewangelie zostały podniesione do tej rangi stosunkowo późno, jeśli patrzymy na początkowy rozwój i kształtowanie się całości pism chrześcijańskich. Ich znaczenie jednak polegało na otwieraniu drogi do coraz bardziej właściwego odczytania, a tym samym także zweryfikowania teologiczno-krytycznego innych pism: ksiąg, listów, opowiadań czy nawet fantastycznych przekazów, które pretendo-

\footnotetext{
1 Ks. prof. dr hab. Janusz Królikowski, kierownik Katedry Teologii Dogmatycznej na Wydziale Teologicznym Sekcja w Tarnowie Uniwersytetu Papieskiego Jana Pawła II w Krakowie; e-mail: jkroliko@poczta.onet.pl; ORCID: 0000-0003-3929-6008.

2 Por. J. Królikowski, Od jednej Ewangelii Chrystusa do czterech Ewangelii Kościoła, VoxP 71 (2019) s. 351-372.
} 
wały wraz z nimi do konstytuowania „Nowego Testamentu”. To określenie miało poniekąd charakter syntetyczny, to znaczy zamierzano za jego pomocą uporządkować całość pojawiających się zagadnień odnośnie do najważniejszych pism chrześcijańskich, chociaż przyjęcie tej całości nie oznaczało wprost jakiegoś uporządkowania hierarchicznego różnych jednostek literackich. W pewnym przynajmniej sensie Ewangelie już pod koniec II wieku zaczynały stanowić dla Nowego Testamentu to, czym było Prawo Mojżeszowe dla Starego Testamentu w rozumieniu tradycji żydowskiej. Stopniowo Nowy Testament zaczął przybierać strukturę dzisiejszą (Ewangelie, listy i inne pisma). W pierwszych latach III wieku w basenie Morza Śródziemnego, od Kartaginy i Rzymu na Zachodzie do Aleksandrii i innych znaczących ośrodków na Wschodzie, na pewno istniał już, przynajmniej w sensie ogólnym, „Nowy Testament” jako pewna odrębna rzeczywistość literacka określana tym właśnie mianem. Rodziła się w pełnym znaczeniu tego słowa Biblia chrześcijańska, chociaż nie była jeszcze nazywana „Biblią”, co dokona się stosunkowo późno, bo dopiero pod koniec średniowiecza. Używano najczęściej określeń „Pismo - Pisma” (Scriptura - Scripturae) lub „święte Pismo - święte Pisma” bądź też „księgi święte”. Pojawiały się też inne określenia, niekiedy nawet bardzo sugestywne, ale nie uzyskały one takiego samego znaczenia $^{3}$. Trzeba będzie jednak jeszcze dłuższego czasu, aby ta całość literacka zyskała rangę oficjalną i została skodyfikowana doktrynalnie właśnie jako całość. Nastąpi to dopiero pod koniec IV wieku, gdy pojawi się już skodyfikowany „kanon Pism”, na którego powstanie zwraca się szczególną uwagę w aktualnych badaniach historyczno-biblijnych ${ }^{4}$. Jest to zagadnienie bardzo ważne także dla teologii, dlatego szerzej zwrócimy na nie w najbliższym czasie uwagę.

W tym miejscu zamierzamy omówić jeden z czynników, który wydatnie przyczynił się do wspomnianego skodyfikowania Pism chrześcijańskich oraz wyraźnie wpłynął na określenie ich tożsamości w relacji do Pism żydowskich, zachowując zarazem z nimi teologiczną jedność i ciągłość. Tym czynnikiem jest użycie w odniesieniu do Pism chrześcijańskich miana „Testamentu”. Samo zagadnienie jedności teologicznej wszystkich ksiąg biblijnych oraz jej przesłanie teologiczne zasługuje na osobną uwagę, dlatego należałoby się nim szerzej zająć zarówno z historycznego, jak i teologiczno-systematycznego punktu widzenia.

3 Por. A. Paul, Les diverses dénominations de la Bible, „Recherches de Science Religieuse" 83 (1995) s. 373-402.

4 Por. A. Le Boulluec, Le problème de l'extension du Canon des Écritures aux premiers sicéles, „Recherches de Science Religieuse” 92 (2004) s. 45-87. 


\section{Pojęcie „testamentu” w literaturze starożytnej}

Określenia „Stary Testament” (gr. palaia diathēkē) i „Nowy Testament” (gr. kainē diathēkē) pojawiły się w II wieku na oznaczenie dwóch grup świętych pism tworzących korpus literacki, który pewnego dnia - jak już zostało wyżej zaznaczone - zostanie nazwany „Biblią”. Pojawienie się tych pism, a następnie ich utrwalenie, dokonało się w łonie starożytnej wspólnoty kościelnej i w jej ramach nabrało właściwego oraz specyficznego znaczenia, przy czym jest jasne, że wspólnota kościelna czerpała inspiracje także z kulturowych i semantycznych dziejów greckiego słowa diathēke $\bar{e}^{5}$, w odniesieniu do którego kształtowała się jej świadomość i tożsamość. Tak było niemal zawsze i dlatego musimy na tę kwestię stale zwracać uwagę, mając na celu przede wszystkim pokazanie oryginalności chrześcijaństwa w stosunku do wcześniejszych doświadczeń kulturowych, filozoficznych czy prawnych oraz jego ogromnego wysiłku intelektualnego zachowującego swoje znaczenie do dnia dzisiejszego, nawet jeśli bywa to coraz szerzej deprecjonowane ${ }^{6}$.

Demokryt i Arystofanes (V-IV wiek przed Chrystusem) stosują rzeczownik diathēkē w sensie decyzji woli lub testamentu. Pochodzi on od czasownika diatithēmi oznaczającego 'posiadać władzę nad osobami i rzeczami', a ściślej rzecz ujmując, na podstawie dokumentów prywatnych o znaczeniu prawnym (np. papirusy) można określić jego znaczenie jako 'dysponować za pośrednictwem swojej woli'. Chodzi o decyzję nieodwołalną lub o jednostronny akt osoby w odniesieniu do jakiejś sprawy czy spraw. Diathēkē różni się od pokrewnego pojęcia synthē $k \bar{e}$, którego użycie było zarezerwowane dla określania ,porozumienia” lub ,przymierza/paktu” między dwoma partnerami. Słowo oznacza dokument prawny, który określa następowanie po sobie faktów (testament w sensie ścisłym) i zajmuje wiele miejsca już w starożytnym prawie prywatnym. Żydowski historyk Józef Flawiusz, który pisze (lub dyktuje) po grecku, jako pierwszy odwołuje się do pojęcia diathēkē. Odnosi je do „testamentu” królowej Kleopatry (69-30 przed Chrystusem) ${ }^{7}$. W swoim dziele Józef Flawiusz posługuje się tym słowem jeszcze piętnaście razy, zawsze w sensie dyspozycji testamentowej.

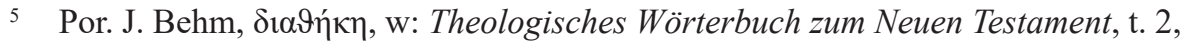
red. G. Kittel - G. Friedrich, Stuttgart 1935, s. 106-137.

6 Por. np. Ch. Freeman, La fine del pensiero occidentale. Il sorgere della fede e il crollo della ragione, Milano 2016 (tytuł oryginału: The closing of the Western Mind). Autor w sposób całkowicie kuriozalny próbuje dowieść, że pojawienie się chrześcijaństwa doprowadziło do zakwestionowania rozumu.

7 Flavius Iosephus, Antiquitates Judaicae 13, 1, tł. Z. Kubiak - J. Radożycki, Józef Flawiusz, Dawne dzieje Izraela. Antiquitates Iudaicae, Poznań - Warszawa - Lublin 1962, s. 640. 
Diathēkē stanie się stopniowo specyficznym gatunkiem literackim. Znamy bardzo starożytnych świadków pierwotnych przemian zachodzących w rozumieniu tego słowa, choć nie są oni zbyt liczni. Mamy więc do dyspozycji „testamenty” (diathēkai) filozoficzne Platona, Arystotelesa, Teofrasta, Epikura i kilku innych. Reprezentują one szczególny gatunek literacki, który jest studiowany i opisywany przez filozofów, ponieważ pozwala ich bliżej poznać, także dlatego że pojawiają się w testamentach kwestie filozoficzne, ale mimo to te wypowiedzi nie oddalają się w jakiś zasadniczy sposób od struktury i sensu tego gatunku literackiego. Pierwszy znak faktycznej zmiany pojęcia diathēke, w którym znaczenie prawne pojęcia przechodzi w znaczenie literackie, odnotowujemy w diathēkai filozofa cynika Menipposa z syryjskiej Gadary (koniec IV lub początek III wieku przed Chrystusem) ${ }^{8}$. Kilka wieków później pojawiają się diathēkai słynnego kaznodziei i cudotwórcy współczesnego Jezusowi Apoloniusza z Tiany. Flawiusz Filostratos dokonał ich streszczenia w Żywocie Apoloniusza na końcu II wieku.

Forma testamentu literackiego była stosowana także przez pisarzy żydowskich posługujących językiem greckim ${ }^{10}$. Prawdopodobnie w II wieku przed Chrystusem, być może w Aleksandrii, powstało dzieło zatytułowane Testament Orfeusza. Chodzi o tekst posiadający rysy żydowskie, choć wskazuje się także na jego podobieństwo do diathēkai Menipposa z Gadary. W ostatnich latach II wieku Klemens z Aleksandrii, tym razem należący do tradycji chrześcijańskiej ${ }^{11}$, stwierdza, że diathêkē na ogół oznacza pewną całość tekstów, na przykład autorstwa filozofów. Wielki Aleksandryjczyk zapisał: „Filozofia została dana Hellenom [...] jako zapis testamentowy”12.

\section{Tradycja biblijna i jej dojrzewanie}

Przywołane przykłady prawnego i literackiego stosowania pojęcia diathe $\bar{k} \bar{e}$ wystarczająco ilustrują jego użycie w tradycji helleńskiej. Bardzo

8 Por. Diogenis Laertii Vitae philosophorum 6, 99-101, tł. I. Krońska - K. Leśniak - W. Olszewski - B. Kupis, Diogenes Laertios, Żywoty i poglady stynnych filozofów, Warszawa 1968, s. 363-364.

9 Filostratus, Vita Apollonii, tł. I. Kania, Flawiusz Filostratos, Żywot Apoloniusza z Tiany, Kraków 1997.

10 Por. J.H. Charlesworth, Pseudoepigrafy, w: Encyklopedia biblijna, red. P.J. Achtemeier, Warszawa 1999, s. 1028-1029.

11 Por. G.I. Gargano, Clemente e Origene nella Chiesa cristiana alessandrina. Estaraneità, dialogo o inculturazione?, Cinisello Balsamo 2011.

12 Clemens Alexandrinus, Stromata, 6, 8, 67, 1. 
wcześnie, bo jeszcze w czasach przedchrześcijańskich, weszło ono także do greckiego języka biblijnego. Septuaginta posłużyła się tym pojęciem $\mathrm{w}$ tłumaczeniu hebrajskiego bərît ('przymierze') ${ }^{13}$. Bardzo rzadko pojawia się w tym thumaczeniu słowo synthē $k \bar{e}$, które oznacza 'pakt/przymierze' lub 'traktat'. Można by tymczasem oczekiwać, że w tłumaczeniu zostanie zastosowane to drugie pojęcie, tym bardziej, że często posługuje się nim Józef Flawiusz w swoich parafrazach biblijnych zawartych w Dawnych dziejach Izraela (Antiquitates Iudaicae). Nowy Testament przyjmuje rozwiązanie zastosowane w Septuagincie, otwarcie opowiadając się za kaine diathēke ('nowe przymierze') zapowiedzianym przez proroka Jeremiasza $(\mathrm{Jr} 31,31)^{14}$, a nawet opierając się na nim jako swoim ,fundamencie"15.

W greckiej wersji Starego Testamentu nierzadko możemy znaleźć znaki stopniowego ewoluowania pojęcia diathēkē w kierunku znaczenia literackiego. W Księdze Wyjścia czytamy na przykład, że Mojżesz „wziął Księgę Przymierza i czytał ją głośno ludowi” (Wj 24,7). W języku hebrajskim mamy tutaj seper habbərît, a w języku greckim - biblion tēs diathēkēs. Ma tutaj miejsce utożsamienie przymierza z tekstem. Podobna wypowiedź znajduje się w Drugiej Księdze Królewskiej, wskazując prawdopodobnie na Księgę Powtórzonego Prawa (2Krl 23,2.21). Nieco wcześniej jest ona nazwana „księgą Prawa” (2Krl 22,8). W późniejszym okresie, pod koniec II wieku przed Chrystusem, określenie biblion diathē $k \bar{e} s$ ('Księga Przymierza') powróci w Pierwszej Księdze Machabejskiej, wskazując na „Prawo Mojżesza” (1Mch 1,57). Septuaginta zdanie z Księgi Daniela „to, co zostało zapisane w tôrāh Mojżesza” tłumaczy przez „to, co zostało zapisane w diathēkē Mojżesza" (Dn 9,13). Jest to tym bardziej znaczące, że inny, późniejszy tłumacz Pism żydowskich na język grecki, Teodocjon z Efezu, oddał tekst hebrajski za pośrednictwem słowa nomos ('prawo').

Geneza literackiego rozumienia i stosowania pojęcia diathêkē może być szukana jednak także na innej drodze, która pokazuje poszerzanie się jego pola semantycznego. W tradycji biblijnej znajdujemy więc teksty, które nawet jeśli nie są wprost nazywane „testamentami”, to jednak swoją treścią i sformułowanym przesłaniem wyraźnie odsyłają do tego gatunku literackiego. Teksty tego typu $\mathrm{w}$ samej Biblii i w komentarzach redakcyjnych na ogół są nazywane „błogosławieństwami”, którego udzielali umierający ojcowie swoim rodzinom lub po prostu „mowami pożegnalnymi”. Można tutaj przywołać postacie Izaaka (Rdz 27), Jakuba (Rdz 48-49), Mojżesza

13 Por. A. Malina, Czy Nowy Testament mógtby powstać bez Septuaginty?, „Tarnowskie Studia Teologiczne” 35/1 (2016) s. 149-151.

14 Por. A. Jankowski, Biblijna teologia przymierza, Kraków 1997.

15 Por. O. Becker, Alleanza, w: Dizionario dei concetti biblici del Nuovo Testamento, red. L. Coenen - E. Beyreuther - H. Bietenhard, Bologna 1989, s. 67. 
(Pwt 33), Jozuego (Joz 23-24), Samuela (1Sm 12), Dawida (1 Krl 2), Tobiasza (Tb 14) i Matatiasza (1Mch 2,49-70). Ich odejście z tego świata jest wyraźnie wiązane z przekazywanym osobistym przesłaniem mającym formę ostatniej woli, czyli testamentu. To przesłanie, niekiedy bardzo konkretne, wskazuje między innymi sposoby korzystania z otrzymanego dziedzictwa.

Ta forma literacka znajduje się $w$ pseudoepigrafach Starego Testamentu, w tekstach o charakterze mocno apokaliptycznym. Na końcu I wieku Apokalipsa Barucha mogła być czytana jako zbiór testamentów ${ }^{16}$. Powstała w tym samym czasie Czwarta Księga Ezdrasza, składająca się z siedmiu wielkich wizji, w ostatniej z nich jest testamentem ${ }^{17}$. Określenie „Testament” służące za tytuł (subscriptio) w późniejszym okresie zostanie nadany licznym nawiązującym w sensie literackim do Biblii księgom napisanym przez żydów zarówno w ich ojczyźnie, jak i w diasporze w ciągu dwóch lub trzech wieków poprzedzających pojawienie się chrześcijaństwa. Z niewielkimi wyjątkami, na przykład dotyczy to Biblii ormiańskiej lub Biblii etiopskiej, które uwzględniają Księge Henocha lub Księge Jubileuszów, Kościoły chrześcijańskie, tak na Zachodzie, jak i na Wschodzie nie uwzględniły ich w kanonie biblijnym. W tradycji katolickiej są one najczęściej nazywane apokryfami ${ }^{18}$.

Także w Nowym Testamencie spotykamy analogiczne zjawisko literackie. Św. Paweł w Milecie wygłasza mowę pożegnalną do Efezjan (Dz 20,14-35). Przemawia jako ten, który spodziewa się, że już nie będzie miał okazji do kolejnego spotkania: „Już mnie nie ujrzycie” (Dz 20,25). Mowa św. Pawła posiada więc wyraźne cechy testamentu ${ }^{19}$. Nie można także zapomnieć o zakończeniach Ewangelii św. Mateusza (28,16-20) i św. Łukasza (24,26-53; por. Dz 1,3-9). Na szczególną jednak uwagę zasługuje długa i nośna teologicznie mowa pożegnalna wypowiedziana przez samego Jezusa w Wieczerniku na progu opowiadania o Jego męce w Ewangelii św. Jana (J 13-17).

Spotykamy więc różne rodzaje wykorzystania testamentów. Testamenty stanowią część większych jednostek literackich bądź też same są samoistnymi jednostkami literackimi, czyli księgami we właściwym znaczeniu

16 Por. Liber Apocalypseos Baruch, tł. J. Woźniak, Apokalipsa Barucha, w: Apokryfy Starego Testamentu, opr. R. Rubinkiewicz, Warszawa 1999, s. 407-442.

17 Por. IV Esdras, tł. S. Mędala, Czwarta Księga Ezdrasza, w: Apokryfy Starego Testamentu, opr. R. Rubinkiewicz, Warszawa 1999, s. 402-403.

18 Por. J. Królikowski, Jak powstała Wulgata i któremu tekstowi Pisma Świętego przystuguje to miano?, „Tarnowskie Studia Teologiczne” 36/1 (2017) s. 10.

19 Por. J. Dupont, Le Discours de Millet. Testament pastoral de Saint Paul, Paris 1962. 
tego słowa. Najpierw posługiwali się nimi Żydzi, a potem wykorzystali je także chrześcijanie. Tytułem przykładu można przywołać Testamenty dwunastu Patriarchów ${ }^{20}$, Testament Mojżesza ${ }^{21}$, Testament Abrahama ${ }^{22}$ i Testament Hioba ${ }^{23}$ - wszystkie te pisma są współczesne pismom Nowego Testamentu. Niektóre z tych tekstów zostały zredagowane w języku hebrajskim lub aramejskim, a potem zostały przetłumaczone na język grecki, łaciński i na inne języki. Niektóre zostały napisane wprost po grecku. Chodzi o dzieła bardzo ważne, gdyż miały one potem wielki wpływ na ukonstytuowanie się pierwszych tekstów chrześcijańskich. Dzięki chrześcijanom nie uległy one zapomnieniu, a nawet można zasadnie twierdzić, że chrześcijanie uchronili je przed zniszczeniem, razem z pismami Filona Aleksandryjskiego i Józefa Flawiusza, o których istnieniu Żydzi dowiedzieli się dopiero po wynalezieniu druku.

\section{3. „Testament” u św. Pawła}

Pojęcie diathēke rozpatrywane w perspektywie biblijnej jest wyraźnie naznaczone pewną wieloznacznością. Znaki następującego przejścia od religijnego znaczenia przymierza do literackiego sensu testamentu są wyraźnie widoczne w Biblii, chociaż przesunięcie akcentów dokonywało się bardzo powoli, w znacznym stopniu zależąc od potrzeb religijnych i okoliczności historycznych. Ta wieloznaczność, nigdy nieusunięta i nigdy niezwalczana, weszła do dziedzictwa pozostawionego przez Żydów chrześcijanom, którzy ze swej strony podjęli jednak szerszą refleksję zmierzającą do rozróżnienia i sprecyzowania dwóch sensów, które niesie z sobą diathēkē.

Pierwszym wielkim świadkiem podjęcia tej refleksji jest juź św. Paweł Apostoł, który wyprowadził $\mathrm{z}$ niej także bardzo określone wnioski, co szczególnie jest widoczne w Drugim Liście do Koryntian:

On [Bóg] też sprawił, że mogliśmy stać się sługami Nowego Przymierza (diathēkê), przymierza nie litery, lecz Ducha, litera bowiem zabija, Duch zaś

20 Por. Testamenta XII Patriarcharum, tł. A. Paciorek, Testament dwunastu Patriarchów, w: Apokryfy Starego Testamentu, opr. R. Rubinkiewicz, Warszawa 1999, s. 43-81.

21 Por. Testamentum Mosis, w: M. Parchem, Testament Mojżesza. Wprowadzenie oraz przektad z objaśnieniami, „Collectanea Theologica” 76/2 (2006) s. 79-103.

22 Por. Testamentum Abrahae, tł. M. Wittlieb, Testament Abrahama, w: Apokryfy Starego Testamentu, opr. R. Rubinkiewicz, Warszawa 1999, s. 82-100.

${ }_{23}$ Por. Testamentum Jobi, tł. A. Tronina, Testament Joba, w: Zmartwychwstal prawdziwie, red. A. Paciorek - A. Tronina - P. Łabuda, Tarnów 2010, s. 519-548. 
ożywia. Ale jeśli posługiwanie śmierci, utrwalone literami w kamieniu, dokonywało się w chwale, tak iż synowie Izraela nie mogli spoglądać na oblicze Mojżesza z powodu blasku jego oblicza, który miał przeminąć, to o ileż pełne chwały będzie posługiwanie Ducha? [...] Ale stępiały ich umysły. I tak aż do dnia dzisiejszego, gdy czytają Stare Przymierze (palaia diathēkēe), pozostaje nad nimi ta sama zasłona, bo odsłania się ona w Chrystusie (2Kor 3,6-8.14) ${ }^{24}$.

Dobrze będzie zauważyć użycie literackie słowa diathēkē w tym tekście w epoce jego redakcji, nawet jeśli jest ono także naznaczone pewną dwuznacznością semantyczną. Nie wydaje się ani przesadą, ani nie razi ahistoryzmem przetłumaczenie go raczej jako 'testament' niż jako 'przymierze', przynajmniej w drugim przypadku, ponieważ jest jasne, że św. Paweł odnosi się do czegoś, co jest przeznaczone do czytania, czyli do tekstu ${ }^{25}$. W tym czasie pojawiają się już chrześcijańskie pojęcia Starego i Nowego Testamentu, chociaż wówczas nie było jeszcze kompletnego zestawu ani tekstów, ani ksiąg, które mogłyby być określone jako Nowy Testament. Ściśle literackie znaczenie tego określenia jest jeszcze w fazie zarodkowej - jest to pewien model, który jeszcze czeka na urzeczywistnienie. W stwierdzeniach św. Pawła jest jednak zawarte coś profetycznego. Następująca ewolucja pojęcia diathēke osiągnie pełną dojrzałość właściwie pod jednym warunkiem, a mianowicie dojdzie do niej w tym momencie, gdy zostanie opracowany korpus literacki wystarczająco organiczny, różniący się od dziedzictwa żydowskiego, który będzie mógł zostać uznany za „Pismo Testament”. Taki korpus został rzeczywiście wypracowany w późniejszym okresie, już po św. Pawle, i uznany za Pismo przez wspólnotę chrześcijańską. Jako niedawny i odrębny w swoim pochodzeniu stał się on w pełnym znaczeniu tego słowa „nowym” korpusem literackim. Na zasadzie kontrastu wynikającego z chronologicznego usytuowania dwóch rzeczywistości te „nowe” Pisma sprawiły, że wcześniejsze Pisma żydowskie stały się po prostu „stare” i taką też otrzymały nazwę. Ukształtowanie się Nowego Testamentu doprowadziło więc na zasadzie bezpośredniej konsekwencji historyczno-logicznej do pojawienia się także „Starego Testamentu”. Dla chrześcijan był ważny przede wszystkim Jezus Chrystus i to zainteresowanie Nim doprowadziło w późniejszym okresie do postawienia pytań o Jego związek z tradycją żydowską, w tym z należącymi do niej pismami. Dla zdecydowanej większości chrześcijan nie ulegało jednak wątpliwości,

24 Tłumaczenie według piątego wydania Biblii Tysiąclecia. Por. A. Paciorek, Drugi List do Koryntian. Wstęp, przektad z oryginału, komentarz, Częstochowa 2017, s. 180-191 i 205-207.

25 W języku polskim oddaje ten fakt tylko tłumaczenie ks. Jakuba Wujka. 
że Pisma żydowskie są także ich Pismami i mówią one o Bogu, w którego oni wierzą i o którym mówią, a zwłaszcza mówią o Jezusie Chrystusie, w którym wypełniły się Pisma ${ }^{26}$. Zapoczątkowali oni to, co w późniejszych wiekach stanie się argumentem ex prophetia w apologetyce kościelnej wykorzystywanym głównie w chrystologii, ale także w innych działach teologii.

\section{4. Świadomość pierwotnej wspólnoty kościelnej}

Między końcem II i początkiem III wieku autorzy kościelni potwierdzają, że dokonało się już znaczące przejście semantyczne w odniesieniu do diathēkē. „Testament” osiągnął definitywne znaczenie literackie, chociaż nie było to jeszcze wyłączne znaczenie tego słowa ${ }^{27}$. Zawdzięczamy św. Ireneuszowi kluczowy rozwój doktryny dotyczącej dwóch „przymierzy”. Antyteza między „starym” i ,nowym” przymierzem pochodziła prawdopodobnie z Azji Mniejszej, gdzie urodził się także ten wielki teolog. Kwestia przez dłuższy czas pozostawała kwestią religijną (doktrynalną), ale nie przeszkodziło to w konsekwentnym następowaniu ewolucji znaczeniowej zmierzającej do ujęcia problematyki w sensie literackim, tym bardziej, że w tym samym czasie konstytuowały się i utrwalały pisma chrześcijańskie, które były uznawane za księgi „nowego przymierza” (kainē diathēkē). Ireneusz zestawia Prawo Mojżeszowe z nową diathēkē i dokonuje pogłębionego opisania „różnic pomiędzy Testamentami, a także tego, co je łączy i w czym ze sobą współbrzmią"28. Odnosi się wyraźnie wrażenie, że w prowadzonej analizie ma on na myśli raczej ,przedmiot” literacki niż przymierze jako rzeczywistość wydarzeniową. W każdym jednak razie, łącząc ze sobą dwa korpusy literackie, stary i nowy, oraz widząc ich wewnętrzną ciągłość i jedność jako dwóch dopełniających się Testamentów, Ireneusz rozwija koncepcję doktrynalną wypełnienia prawa (diathēkē) Mojżeszowego przez prawo Ewangelii, które również jest diathēkē. Mimo

26 Por. P. Tremolada, ,Bisogna che si compiono tutte le cose scritte su di me nella legge di Mosè, nei profeti e nei Salmi” (Lc 24,44). Il compimento ,canonistico-cristologico" delle Scritture in Lc-At, w: Rivisitare il compimento. Le Scritture d'Israele e la loro normatività secondo il Nuovo Testamento. Atti del VI Seminario biblico di Teologia del Libro, 22 marzo 2005, Facoltà Teologica dell'Italia Settentrionale, red. S. Romanello R. Vignolo, Milano 2006, s. 41-73.

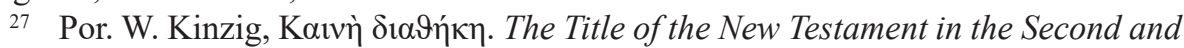
Third Centuries, „Journal of Theological Studies” 45 (1994) s. 519-544.

28 Irenaeus, Adversus haereses 3, 12, 12. 
jasnej wizji teologicznej, którą sformułował Ireneusz, zwłaszcza w odniesieniu do powszechnej rekapitulacji w Jezusie Chrystusie, wydaje się, że zastosowanie przez niego pojęcia diathēke w sensie „testamentu” nie jest jeszcze jednoznaczne i określone treściowo.

Klemens Aleksandryjski jest innym świadkiem posuniętej jeszcze dalej dojrzałości chrześcijańskiego rozumienia pojęcia diathēkē w sensie literackim, chociaż i on nie wypowiada się definitywnie na ten temat ${ }^{29}$. Klemens jest młodszy od Ireneusza i zna jego dzieła. Wielokrotnie w dziele Klemensa palaia diathēkē ma znaczenie „starego testamentu”, a nea diathēke - znaczenie „nowego testamentu”, przy czym stanowią one dla niego jedność religijną. Pisze on na przykład: „Czyż nie to samo przykazuje Pan w Starym Testamencie?" ${ }^{30}$. Klemens podkreśla bardzo mocno, że nowe Pisma narodziły się w odpowiedzi na praktyczne wyzwania, przed którymi stawała pierwotna wspólnota chrześcijańska i jako wynik podejmowanej wówczas refleksji. W tym czasie te nowe Pisma stanowiły już prawdziwy i właściwy korpus przyjęty i wykorzystywany w Kościele. Mimo to dla Klemensa pojęcie diathēkē nie tylko miało znaczenie „testamentu”, lecz także wskazywało na „przymierze” Boga z ludzkością - przymierze, które ogłosił Jezus Chrystus i które osobowo urzeczywistnił w sobie, w związku z czym musiało być ono ,nowe" i jako takie jest przyjmowane przez Kościół. Klemens stwierdza jednoznacznie: „A normą Kościoła jest zbieżność i zgodność Prawa i proroków z Nowym Przymierzem zawartym w czasie obecności Pana"31.

Ostatecznie jednak trzeba powiedzieć o Klemensie to samo, co zostało powiedziane o Ireneuszu z Lyonu, który zapewne był dla niego źródłem natchnienia i ukierunkował jego refleksję, a mianowicie że jeśli odnosimy się do Pism, które zostają uznane przez niego za „nowe”, to jeszcze nie da się u niego w sposób ścisły wyznaczyć granicy między użyciem pojęcia diathe $\bar{k} \bar{e} \mathrm{w}$ sensie literackim i w sensie wydarzeniowym. Granica pozostaje jeszcze nieokreślona i domaga się dalszego sprecyzowania, będąc na nie wyraźnie otwarta.

Po raz pierwszy diathēkē zostało zastosowane w sensie technicznym i ściśle literackim do ksiąg biblijnych w pismach Melitona z Sardes (zm. przed 190 rokiem) ${ }^{32}$. Należał do tego samego środowiska, z którego wywodził się św. Ireneusz. Euzebiusz z Cezarei tak o nim pisze:

29 Por. A. Le Boulluec, De l'usage de titres ,néotestamentaires” chez Clément d'Alexandrie, w: La formation des canons scripuraires, ed. M. Tardieu, Paris 1993, s. 191-202.

30 Clemens Alexandrinus, Stromata 3, 6, 54, 4.

31 Clemens Alexandrinus, Stromata 6, 15, 125, 3-4.

32 Por. R.M. Leszczyński, Meliton z Sardes, EK XII 505-506. 
We wstępie do swych Wypisów (Eclogae) ten sam autor [Meliton] umieszcza katalog (katalogos) powszechnie uznawanych pism Starego Testamentu. Podanie go tutaj jest konieczne. Oto jego słowa: „Meliton pozdrawia brata Onesimosa. Ponieważ powodowany żarliwością w odnoszeniu się do słowa Bożego często wyrażałeś życzenie, że chcesz znać dokładną liczbę i porządek ksiąg Starego Testamentu (ta palaia biblia), postarałem się to zrobić. [...] Zatem byłem na Wschodzie i dotarłem do miejsca, gdzie to wszystko było głoszone i gdzie się działo; tam poznałem dokładnie księgi Starego Testamentu (ta tes palaias diathēkēs biblia), posyłam ci ich zestawienie" 33 .

Wypowiedź jest bardzo jasna i zawarte w niej przesłanie będzie stopniowo, nie budząc żadnych kontrowersji, utrwalać się we wspólnocie kościelnej. Określenie „księgi Starego Testamentu” koresponduje z określeniem „Stary Testament”, które szybko zdobędzie pierwszeństwo w języku kościelnym. Sens literacki „testamentu” narzuci się już raz na zawsze, a dokona się to bez większych trudności. Bardzo szybko pojawi się także przymiotnik endiathekos - spotykamy go u Orygensa i wielokrotnie odwołuje się do niego Euzebiusz z Cezarei ${ }^{34}$ - który oznacza 'należący do ksiąg Testamentu'. Można by próbować go przetłumaczyć jako 'utestamentowiony', choć nie brzmi to dobrze. W sposób pośredni korpus literacki uznany przez chrześcijan za ,święty” połączył się z zestawem znanych w starożytności testamentów literackich, zyskując tym samym także lepsze rozumienie w starożytnym środowisku kulturowym.

Rozszerzenie się kulturowe Kościoła o język łaciński, oczywiście w ścisłej łączności z językiem greckim i jego osiągnięciami w dziedzinie teologii, było kolejnym etapem, który przyczynił się do dalszego utrwalenia znaczenia pojęcia diathe $\bar{k} \bar{e} \mathrm{w}$ sensie „testamentu” oraz nadania mu zdecydowanego pierwszeństwa w języku chrześcijańskim. Około 200 roku Tertulian jest świadkiem użycia formuły vetus et novum testamentum, chociaż rzadko się do niej odwołuje, opowiadając się raczej za formułą vetus et novum instrumentum. Dokonując przeglądu wypowiedzi Tertuliana, wydaje się, że kluczową sprawą było dla niego raczej ukazanie teologicznej „nowości” i specyfiki pism chrześcijańskich niż zastanawianie się nad tym, jak je nazwać ${ }^{35}$. Samo pojęcie testamentu wydaje się być zwykłą konsekwencją dostrzeżenia, że to, co nowe, różni się od tego, co wcześniejsze w dziedzinie posiadania, przy czym to, co wcześniejsze, jest otrzymanym dziedzictwem, jak w prawie spadkowym. Pojęcia testamentum i instrumentum były używane w prawie rzymskim. Pierwsze wskazywało na akt ostat-

\footnotetext{
33 Eusebius Caesariensis, Historia ecclesiastica 4, 26, 13-14.

34 Por. Eusebius Caesariensis, Historia ecclesiastica 3, 3, 1 i 3; 3, 25, 6; 6, 25, 1.

35 Tertullianus, Adversus Marcionem 4, 1.
} 
niej woli, drugie natomiast oznaczało spisany kontrakt lub porozumienie. Po Tertulianie chrześcijańscy autorzy łacińscy, mówiąc o swoich Pismach, będą stopniowo przyznawać pierwszeństwo określeniu testamentum, czyniąc z niego ważny element tożsamości chrześcijańskiej, chociaż na pewno jeszcze długo będą korzystać z określenia instrumentum ${ }^{36}$. Właściwe i powszechne przyjęcie określeń Stary i Nowy Testament dokona się w połowie IV wieku, przechodząc w późniejszym okresie do wszystkich języków europejskich. Wydaje się, że najbardziej konsekwentny w stosowaniu formuły „Stary i Nowy Testament” jest św. Augustyn, dla którego posiadała ona wyjątkowe znaczenie teologiczne ${ }^{37}$, a za nim szybko potem poszedł krąg jego uczniów i zwolenników. Na pewno sprzyjały temu także tendencje kulturowe i intelektualne kładące coraz większy nacisk na zasadnicze znaczenie tego, co spisane i utrwalone na sposób literacki ${ }^{38}$.

\section{Zakończenie: nowość chrześcijańska}

Ruch religijno-intelektualny, który doprowadził Kościół do uznania za „nowe” tych Pism, których on sam był twórcą, a za „stare” Pism żydowskich, których stawał się dziedzicem, odznacza się całkowicie szczególną dynamiką teologiczną nastawioną na określenie tożsamości, którą manifestował on w swoim działaniu oraz kierowaniem się zasadami hermeneutyczno-teologicznymi, które stopniowo odkrywał, formułował i stosował praktycznie. Przymiotnik ,stare” odniesiony do Pism żydowskich nie ma bynajmniej sensu deprecjonującego, ale zwraca na nie uwagę jako pewne źródło religijne, z którego czerpią chrześcijanie jako podstawowe świadectwo minionych dziejów, w których Bóg rzeczywiście wyszedł naprzeciw człowiekowi, jako pierwotne dziedzictwo, z którego nie można zrezygnować, jeśli chce się zachować wierność wobec samego Boga. Kościół nigdy nie kwestionował, że także stare Pisma zawierają wezwanie, które zwraca się do chrześcijan oraz stanowi ich bogactwo religijne i zaplecze duchowe. Nie ma w podkreślaniu nowości tego, co chrześcijańskie, żadnego pomniejszania tego, co w historii zbawienia

36 Por. Rufinus, Apologia contra Hieronymum 2, 32, PL 21, 611.

37 Por. J. Ratzinger, Lud i dom Boży wnauce św. Augustyna o Kościele. Rozprawa doktorska oraz inne opracowania nauki Augustyna i teologii ojców Kościoła, tł. W. Szymona, Lublin 2014, s. 360-372.

38 Por. V.A. Sirago, L'uomo del IV secolo, Napoli 1989; M. Caltabiano, Litterarum lumen. Ambienti culturali e libri tra il IV e il V secolo, Roma 1996; G. Vigini, Il libro cristiano nella storia della cultura, t. 1, Milano 2015. 
działo się wcześniej, a teraz stało się starsze, gdyż nastąpiło wypełnienie tego, co kiedyś było zapowiadane, noszące wyraźne znamiona nowości teologicznej. Chodzi w tym przypadku o stwierdzenie pewnego zakończonego procesu przekroczenia i poszerzenia opartego na interpretacji, którego analogiczne przykłady możemy znaleźć w niektórych pismach z Qumran, zwłaszcza w Zwoju Światynnym (11QT) ${ }^{39}$. Ukonstytuowanie się dwóch Testamentów, które stają niejako naprzeciw siebie, przyczyniło się do jasnego określenia różnicy zachodzącej między chrześcijaństwem a judaizmem, różnicy zarówno literackiej, jak i doktrynalnej. Dzięki dokonującemu się procesowi o charakterze literackim wspólnota chrześcijańska wydatnie postąpiła naprzód w dziedzinie rozpoznania swojej tożsamości religijnej, a tym samym doszła także do określenia zasad nowego stylu życia dotyczących kluczowych jego dziedzin, takich jak liturgia, nauczanie, a w sensie szerszym także aktywnego uczestniczenia w kulturze i w jej rozmaitych przejawach ${ }^{40}$.

Warto tutaj jeszcze zwrócić uwagę, że w tym samym czasie także rabini usiłowali odnowić żydowską tożsamość religijną za pośrednictwem kreowania analogicznego procesu. W pewnym momencie podjęli więc oni wysiłki, aby dopełnić Testament nazywany starym innym testamentem nazywanym nowym, poszerzającym Torę przekazaną Mojżeszowi na Synaju. Ten nowy korpus miał składać się z dwóch koniecznych elementów: starej Tory „spisanej”, czyli miqra' ('pismo'), i Tory „ustnej” z jej „nowymi” wytworami literackimi, którymi są Miszana i Talmud. Tora, stanowiąca dla żydów pełne objawienie, posiadała więc podwójną formę, to znaczy spisaną i ustną. Tora spisana przywołuje więc jako swoje konieczne dopełnienie Torę ustną, a tym samym dowartościowuje dokonujący się proces interpretacji religijnej i egzystencjalnej. Zwraca się dzisiaj uwagę, że możemy w tym przypadku mieć do czynienia z nawiązaniem do tradycji chrześcijańskiej, dla której słowo Boże objawione w swojej doskonałości przez Jezusa Chrystusa przyjęło podwójną rzeczywistość - Stary i Nowy Testament, dzięki czemu Stary Testament staje się spójny i w pełni zrozumiały tylko pod warunkiem, że jest in Novo receptum ${ }^{41}$. Należy ponadto zauwa-

39 Por. E. Dąbrowa, Czy Statuty Królewskie (11QTemple) zawieraja aluzje historyczne?, w: Qumran. Pomiędzy Starym i Nowym Testamentem, red. H. Drawnel - A. Piwowar, Lublin 2009, s. 105-114.

40 Por. S. Morlet, Les chrétiens et la culture. Conversion d'un concept ( $I^{\mathrm{er}}-V I^{\mathrm{e}}$ siècle), Paris 2016.

41 Por. M. Sæbø, Church and Synagogue as the Respective Matrix of the Development of an Authoritative Bible Interpretation. An Epilogue, w: Hebrew Bible / Old Testament. The History of Its Interpretation, t. 1/1, ed. M. Sæbø, Göttingen 1996, s. 731-745. 
żyć, że ten proces na pewno przyczynił się także do zamknięcia kanonu Starego Testamentu ${ }^{42}$, na co także warto by zwrócić uwagę, ponieważ oznacza to, że także chrześcijanie w pewnym momencie wnieśli wkład w ukształtowanie się tożsamości judaistycznej i przynajmniej pośrednio ukierunkowali jej dalszy rozwój.

\section{The Origins of the „Two Testaments” of the Holy Bible}

(summary)

In the everyday Christian language as well as in theology the two parts of the Holy Bible are referred to as the Old and the New Testament. This terminology has its origins in the Bible, but it was gradually shaped on reflection in the times of the Early Church. It resulted from the process of crystallization of the identity of the Christian community, but also from the fact, that "new" Writings appeared and started to become a part of this identity. Therefore, a need arose for determining their relation to the Jewish Writings and for defining their character which was oriented towards fulfilling the old rules. The article is intended to explain how, in the times of the Early Church, the concept of the "two Testaments" was born.

Keywords: Covenant; Bible; Old Testament; New Testament

\section{Geneza „dwóch Testamentów” Pisma Świętego}

(streszczenie)

W codziennym języku chrześcijańskim i w teologii posługujemy się określeniami Stary i Nowy Testament w odniesieniu do dwóch części Pisma Świętego. Język ten posiada źródła biblijne, ale ukształtował się stopniowo w refleksji pierwotnego Kościoła. Wynikało to zarówno z poszukiwania przez wspólnotę chrześcijańską własnej tożsamości, jak i z faktu, że częścią tej tożsamości stawały się „nowe” Pisma. Zachodziła więc potrzeba określenia ich relacji do pism żydowskich oraz ich specyfiki, która pozostawała pod znakiem wypełnienia tego, co stare. Artykuł zamierza pokazać, w jaki sposób narodziła się koncepcja „dwóch Testamentów” w pierwotnym Kościele.

Slowa kluczowe: przymierze; Pismo; Stary Testament; Nowy Testament

42 Por. G. Dorival, L'apport des pères de l'Église à la clôture du Canon de l'Ancient Testament, w: The Biblical Canons, ed. J.-M. Auwers - H.J. de Jonge, Leuven 2003, s. 81-110. 


\section{Bibliografia}

\section{Źródła}

IV Esdras, w: L. Gry, Les dires prophétiques d'Esdras (IV Esdras), t. 1-2, Paris 1938, tł. S. Mędala, IV Księga Ezdrasza, w: Apokryfy Starego Testamentu, opr. R. Rubinkiewicz, Warszawa 1999, s. 375-406.

Apokryfy Starego Testamentu, opr. R. Rubinkiewicz, Warszawa 1999.

Clemens Alexandrinus, Stromata, PG 8, 685-1380, tł. J. Niemirska-Pliszczyńska, Klemens Aleksandryjski, Kobierce zapisków filozoficznych dotyczacych prawdziwej wie$d z y$, t. 1-2, Warszawa 1994.

Diogenes Laërtius, Vitae philosophorum, ed. M. Marcovich, Stuttgart - Lipsia 1999-2002, tł. I. Krońska - K. Leśniak - W. Olszewski - B. Kupis, Diogenes Laertios, Żywoty i poglądy słynnych filozofów, Warszawa 1968.

Eusebius Caesariensis, Historia ecclesiastica, tł. A. Caba, Euzebiusz z Cezarei, Historia kościelna, Kraków 2013.

Filostratus, Vita Apollonii, w: Philostratus, The Life of Apollonius of Tyana, t. 1-2, ed. Ch.P. Jones, Loeb Classical Library 16-17, Cambridge 2005, tł. I. Kania, Flawiusz Filostratos, Żywot Apoloniusza z Tiany, Kraków 1997.

Flavius Iosephus, Antiquitates Judaicae, w: Josephus, Jewish Antiquitates, Books XII-XIV, with an Englisch Translations by R. Marcus, Cambridge 1957, tł. Z. Kubiak - J. Radożycki, Józef Flawiusz, Dawne dzieje Izraela. Antiquitates Iudaicae, Poznań - Warszawa - Lublin 1962.

Irenaeus, Adversus haereses, ed. A. Rousseau - L. Doutreleau, SCh 211, Paris 1974, tł. J. Brylowski, Ireneusz z Lyonu, Adversus haereses, Pelplin 2018.

Liber Apocalypseos Baruch, w: S. Dederding, Apocalypse of Baruch, w: The Old Testament in Syriac, t. 4/3, Leiden 1973, s. 1-50, tł. J. Woźniak, Apokalipsa Barucha, w: Apokryfy Starego Testamentu, opr. R. Rubinkiewicz, Warszawa 1999, s. 407-442.

Rufinus, Apologia contra Hieronymum, PL 21, 541-624.

Tertullianus, Adversus Marcionem, ed. A. Kroymann, CCL 1, Turnholti 1954, s. 441-726, tł. S. Ryznar, Tertulian, Przeciw Marcjonowi, PSP 58, Warszawa 1994.

Testamenta XII Patriarcharum, w: R. Sinker, Testamenta XII Patriarcharum, Cambridge 1869, tł. A. Paciorek, Testament dwunastu Patriarchów, w: Apokryfy Starego Testamentu, opr. R. Rubinkiewicz, Warszawa 1999, s. 43-81.

Testamentum Abrahae, w: M. Stone, The Testament of Abraham. The Greek Recensions, Missoula 1972, tt. M. Wittlieb, Testament Abrahama, w: Apokryfy Starego Testamentu, opr. R. Rubinkiewicz, Warszawa 1999, s. 82-100.

Testamentum Jobi, w: Testamentum Jobi, ed. J.-C. Picard - S.P. Brock, Pseudoepigrapha Veteris Testamenti Grecae 2, Leiden 1967, tł. A. Tronina, w: Zmartwychwstat prawdziwie, red. A. Paciorek - A. Tronina - P. Łabuda, Tarnów 2010, s. 519-548. 
Testamentum Mosis, w: J. Tromp, The Assumption of Moses. A Critical Edition with Commentary, Leiden 1993.

\section{Opracowania}

Becker O., Alleanza, w: Dizionario dei concetti biblici del Nuovo Testamento, red. L. Coenen - E. Beyreuther - H. Bietenhard, Bologna 1989, s. 66-72.

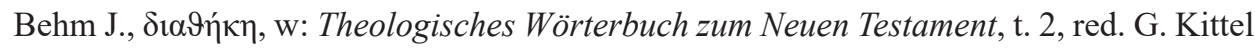
- G. Friedrich, Stuttgart 1935, s. 106-137.

Boulluec A. Le, De l'usage de titres ,néotestamentaires” chez Clément d'Alexandrie, w: La formation des canons scripuraires, ed. M. Tardieu, Paris 1993, s. 191-202.

Boulluec A. Le, Le problème de l'extension du Canon des Écritures aux premiers siecles, „Recherches de Science Religieuse” 92 (2004) s. 45-87.

Caltabiano M., Litterarum lumen. Ambienti culturali e libri tra il IV e il $\mathrm{V}$ secolo, Roma 1996.

Charlesworth J.H., Pseudoepigrafy, w: Encyklopedia biblijna, red. P.J. Achtemeier, Warszawa 1999, s. 1028-1029.

Dąbrowa E., Czy Statuty Królewskie (11QTemple) zawieraja aluzje historyczne?, w: Qumran. Pomiędzy Starym i Nowym Testamentem, red. H. Drawnel - A. Piwowar, Lublin 2009, s. 105-114.

Dorival G., L'apport des pères de l'Église à la clôture du Canon de l'Ancient Testament, w: The Biblical Canons, ed. J.-M. Auwers - H.J. de Jonge, Leuven 2003, s. 81-110.

Dupont J., Le Discours de Millet. Testament pastoral de Saint Paul, Paris 1962.

Freeman Ch., La fine del pensiero occidentale. Il sorgere della fede e il crollo della ragione, Milano 2016.

Gargano G.I., Clemente e Origene nella Chiesa cristiana alessandrina. Estaraneità, dialogo o inculturazione?, Cinisello Balsamo 2011.

Jankowski A., Biblijna teologia przymierza, Kraków 1997.

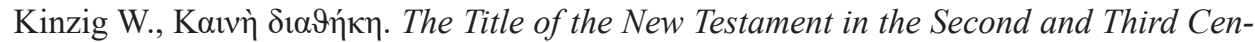
turies, „Journal of Theological Studies” 45 (1994) s. 519-544.

Królikowski J., Jak powstała Wulgata i któremu tekstowi Pisma Świętego przystuguje to miano?, „Tarnowskie Studia Teologiczne” 36/1 (2017) s. 5-20.

Królikowski J., Od jednej Ewangelii Chrystusa do czterech Ewangelii Kościoła, VoxP 71 (2019) s. 351-372.

Leszczyński R.M., Meliton z Sardes, EK XII 505-506.

Malina A., Czy Nowy Testament mógłby powstać bez Septuaginty?, „Tarnowskie Studia Teologiczne" 35/1 (2016) s. 147-170.

Morlet S., Les chrétiens et la culture. Conversion d'un concept (I ${ }^{e r-V I}$ siècle), Paris 2016.

Paciorek A., Drugi List do Koryntian. Wstęp, przekład z oryginału, komentarz, Częstochowa 2017. 
Parchem M., Testament Mojżesza. Wprowadzenie oraz przekład z objaśnieniami, „Collectanea Theologica" 76/2 (2006) s. 79-103.

Paul A., Les diverses dénominations de la Bible, „Recherches de Science Religieuse” 83 (1995) s. 373-402.

Ratzinger J., Lud i dom Boży w nauce św. Augustyna o Kościele. Rozprawa doktorska oraz inne opracowania nauki Augustyna i teologii ojców Kościoła, tł. W. Szymona, Lublin 2014.

Sæbø M., Church and Synagogue as the Respective Matrix of the Development of an Authoritative Bible Interpretation. An Epilogue, w: Hebrew Bible / Old Testament. The History of Its Interpretation, t. 1/1, ed. M. Sæbø, Göttingen 1996, s. 731-745.

Sirago V.A., L'uomo del IV secolo, Napoli 1989.

Tremolada P., ,, Bisogna che si compiono tutte le cose scritte su di me nella legge di Mosè, nei profeti e nei Salmi” (Lc 24,44). Il compimento „,canonistico-cristologico” delle Scritture in Lc-At, w: Rivisitare il compimento. Le Scritture d'Israele e la loro normatività secondo il Nuovo Testamento. Atti del VI Seminario biblico di Teologia del Libro, 22 marzo 2005, Facoltà Teologica dell'Italia Settentrionale, red. S. Romanello - R. Vignolo, Milano 2006, s. 41-73.

Vigini G., Il libro cristiano nella storia della cultura, t. 1 Milano 2015. 